\title{
PHOENICOCICHLA USSHERI.
}

\author{
Ussher's Pitta.
}

Pitta ussheri, Sharpe, Proc. Zool. Soc. 1877, p. 94.-Id. Ibis, 1879, p. 263.-Gould, Birds of Asia, pt. xxix. (1877).-Sharpe, Proc. Zool. Soc. 1881, p. 798.

Since I published my figure of this fine species in the 'Birds of Asia,' the gentleman who discovered this beautiful Pitta, and in whose honour it was named by Mr. Bowdler Sharpe, has passed away. Governor Ussher, when a young man, served on the Gold Coast, where he stayed for nearly sixteen years; and during the whole of this time he was interesting himself in the study of natural history, though for the greater portion of it he was engaged only in collecting insects, many fine species of which were sent home by him to his friend Mr. Andrew Swanzy. A letter which Mr. Sharpe wrote to him, calling his attention to the comparatively unworked field for natural history in the interior of the Gold Coast, induced him to study the ornithology of Denkera and the inner provinces, by means of native collectors; and with such success did he persevere, that in the space of two years he had formed a complete collection of the birds known to occur there up to the year 1869 , while at the same time he sent home many splendid novelties. After leaving the Gold Coast, he was for a short time Governor of Tobago, and then became Governor of Labuan. While in the West Indies his ill-health prevented his collecting much; but when in Borneo he recommenced with all his old energy, and sent over to England exhaustive collections from the island of Labuan itself, as well as from the Lawas river, which he diligently explored, chiefly in the hope of getting living specimens of Bulwer's Pheasant. A full description of these collections was given by Mr. Sharpe in 'The Ibis ' and in the 'Proceedings of the Zoological Society' for 1879. His failing health obliged him at last to quit Labuan for England, where he recovered his strength considerably, and he was, to his great delight, appointed by Mr Disraeli's government to the Gold Coast, for which he set out as Governor in 1879. During his absence from West Africa, the seat of government in that quarter of the globe had been changed from Cape-Coast Castle to Accra; and in the neighbourhood of the latter town the country is more open, and the fauna resembles that of Senegambia rather than that of the rich forest districts to be found inland from the former town. He managed, however, by means of his collectors, to form a considerable collection in Denkera, while he himself worked at the avifauna of his own immediate neighbourhood; and he was about to return to England in December last in the S.S. 'Lualaba' to recruit his health: but it appears that he had delayed his return too long; for he died the day before the arrival of that vessel at Accra. Such is a brief outline of the career of one of England's best colonial governors; and it only shows what material aid to science can be given by an energetic and intelligent official in a foreign country. In the case of Governor Ussher, his loss is mourned not only by the country which he served so well, but also by the English community of natural historians for whom he has done so much successful work.

Ussher's Pitta was discovered by him during his exploration of the Lawas river in North-western Borneo, where it was also met with by Mr. Treacher. It has more recently been procured by Mr. W. B. Pryer in Sandakan, in the north-eastern portion of that island. It is closely allied to Pitta venusta of Java ; but it is distinguished at once from that species by its black colour washed with purple above, as well as by the throat and chest being of the same purplish black; the enamel-like blue markings on the wing are also very much larger and brighter.

The following is a careful description of the typical example :-

General colour above black, with a distinct shade of purple everywhere except on the head, which is glossy black, as well as the lores and sides of the face; from above the eye to the nape runs a distinct superciliary streak of pointed feathers, silvery cobalt in colour, slightly shaded with purple on the hinder plumes; wings blue-black, the median and greater coverts bright cobalt at the tips and on the outer webs, forming an enamel-like patch on the wing; quills black, the inner secondaries externally deep blue; tail deep blue; throat and chest black, the latter strongly washed with purple, shading into the crimson of the breast; rest of the under surface of the body deep crimson; thighs brown; under wing-coverts black.

Total length $6 \cdot 8$ inches, culmen $0 \cdot 85$, wing $3 \cdot 45$, tail $1 \cdot 3$, tarsus $1 \cdot 6$.

The figures in the Plate represent the old bird in two positions, as well as a nestling which I discovered in my own collection, and which doubtless belongs to this species. The figures of the adult are drawn from the typical specimen. 


\section{$2 \mathrm{BHL}$ Biodiversity Heritage Library}

Gould, John. 1881. "Ussher's Pitta, Phœnicocichla ussheri." Monograph of the Pittidae 2, -. https://doi.org/10.5962/p.323523.

View This Item Online: https://www.biodiversitylibrary.org/item/226386

DOI: https://doi.org/10.5962/p.323523

Permalink: https://www.biodiversitylibrary.org/partpdf/323523

\section{Holding Institution}

Smithsonian Libraries

\section{Sponsored by}

Biodiversity Heritage Library

\section{Copyright \& Reuse}

Copyright Status: Public domain. The BHL considers that this work is no longer under copyright protection.

This document was created from content at the Biodiversity Heritage Library, the world's largest open access digital library for biodiversity literature and archives. Visit BHL at https://www.biodiversitylibrary.org. 